\title{
Molecular Docking of Bawang Dayak (Eleutherine bulbosa) Secondary Metabolites as Bacterial Cell Wall Synthesis Inhibitor
}

\author{
Mohammad Rizki Fadhil Pratama ${ }^{1}$, Isna Rasdianah Aziz ${ }^{2}$ \\ ${ }^{1}$ Department of Pharmacy, Faculty of Health Sciences, Universitas Muhammadiyah \\ Palangkaraya, Indonesia. 73111 \\ ${ }^{2}$ Department of Biology, Faculty of Science and Technology, Universitas Islam Negeri \\ Alauddin Makassar, Indonesia. 92113 \\ \{m.rizkifadhil@umpalangkaraya.ac.id ${ }^{1}$, isna.rasdianah@gmail.com ${ }^{2}$ \}
}

\begin{abstract}
This study aims to determine the type of secondary metabolite from bawang dayak with the highest inhibition activity of cell wall synthesis. This research was carried out in silico by docking method using Autodock Vina 1.1.2 on several bawang dayak metabolites on the active site of cell wall synthesis receptors. The main parameter used was the free energy of binding as affinity marker. The docking results showed that among the 24 metabolites used, the highest affinity was shown by eleutherol $\mathrm{A}$, a naphthalene derivative with a $\Delta \mathrm{G}$ value of $-9.4 \mathrm{kcal} / \mathrm{mol}$. The affinity shown is even higher than the natural ligand of the receptor, which shows that eleutherol A has the potential to be developed as an inhibitor of microbial cell wall synthesis. In other words, the isolation of eleutherol A from bawang dayak can be done to increase its potential as an antimicrobial through inhibition of cell wall synthesis.
\end{abstract}

Keywords: Antibacterial, bawang dayak, cell wall synthesis, eleutherol A, molecular docking.

\section{Introduction}

The discovery of new antimicrobial compounds seems to be a need that is never satisfied, especially with the ability of microbes to evolve and become "immune" to the antimicrobials currently used [1]. Many reasons why the development of new antimicrobials tends to lag behind the ability of microbial evolution, one of the most dominant is the time needed for relatively long discoveries, apart from the structure of antimicrobial compounds that are relatively similar to each other [2]. Therefore, the discovery of antimicrobial compounds derived from derivatives of secondary metabolites of medicinal plants is one of the most sought-after alternatives in the discovery of new antimicrobial compounds [3].

Discussing about this, of course the wealth of medicinal plants in Indonesia cannot be underestimated. As the largest archipelago in the world that has thousands of traditional medicinal plants, Indonesia has a lot of potential to develop new antimicrobial compounds from medicinal plants [4]. One of them which has been studied extensively by many researchers is bawang dayak (Eleutherine bulbosa). Bawang dayak are spread in almost all regions in Indonesia, and are traditionally used to treat various diseases, especially those that occur due to 
bacterial infections such as fever, dysentery, diarrhea, and others [5]. The results showed the content of various bioactive secondary metabolites in bawang dayak, especially the tubers, such as eleutherin, eleutherol, and eleutherinol [6]. However, until now there is no known type of metabolite that has the most potent antimicrobial activity.

The antimicrobial activity of a compound itself can be generated through various mechanisms of action. At least there are currently four types of antimicrobial action mechanisms that are known, including inhibition of cell wall, protein, nucleic acid synthesis, and antimetabolites $[7,8]$. Among the four mechanisms of action, activity as an inhibitor of microbial cell wall synthesis may be the most interesting to study. Especially considering that most antibiotics currently experiencing resistance by bacteria come from these types, for example beta blockers such as penicillin derivatives [9]. It is interesting to find out whether the secondary metabolites of bawang dayak have activity as inhibitors of microbial cell wall synthesis.

This study aims to determine the secondary metabolites of bawang dayak with the highest potential as antimicrobials, specifically with the mechanisms of action as cell wall synthesis inhibitors. The study was conducted in silico by molecular docking method to determine secondary metabolites with the highest affinity toward D-alanine-D-alanine ligase, a known cell wall synthesis receptor. Metabolites with the highest affinity then compared with natural ligand of the receptor to determine the level of similarity of amino acid interactions that occur, indicating this potential as an antimicrobial compound with the mechanisms as cell wall synthesis inhibitor.

\section{Material and Methods}

\subsection{Materials}

The hardware used is the ASUS A46CB series Ultrabook with an Intel core i5-3337U @ 1.8 $\mathrm{GHz}$ and Windows 7 Ultimate 64-bit SP-1 operating system. The software used is HyperChem 8.0.8 from Hypercube, Inc., OpenBabel 2.4.1 from OpenBabel.org., And AutoDockTools 1.5.6.rc3 and Autodock Vina 1.1.2 software from The Scripps Research Institute, Inc. Information on 3D dimensional structures of receptor proteins obtained from website of Protein Data Banks (http://rcsb.org), with the protein structure used is D-alanine-D-alanine ligase (Ddl) (PDB ID 2ZDQ), a target protein for inhibition of bacterial cell wall synthesis $[10,11]$.

\subsection{Ligands Preparation}

The ligands used are 24 secondary metabolites which are known to be present in the tuber parts of the bawang dayak as shown in Figure. 1. The ligand used consists of dihydroeleutherinol (1), dihydroisoeleutherin (2), elecanacin (3), eleucanarol (4), eleutherin (5), eleutherinol (6), eleutherinoside A (7), eleutherinoside B (8), eleutherol (9), eleutherol A (10), eleutherol B (11), eleutherol C (12), eleuthinone A (13), eleuthinone B (14), eleuthinone C (15), eleuthoside A (16), eleuthoside B (17), eleuthoside C (18), eleuthraquinone A (19), eleuthraquinone B (20), hongconin (21), isoeleutherin (22), isoeleutherol (23), and karwinaphthol (24) [6, 12-14]. The two-dimensional structure of the ligand is sketched using HyperChem 8.0.8 [15]. All of the compounds then carried out geometric optimization using a semi-empirical approach PM3 to obtain structural conformation that is close to the conditions of these compounds in nature [16]. The format of the optimized structure changes from.log to.pdb using Open Babel 2.4.1. The use of the software makes it very easy to change the format of a ligand from one to another [17]. The docking program used in this study is Autodock Vina 1.1.2. AutoDock Vina is known to 
be one of the software for docking with quite good accuracy and the shortest processing time. All ligands are then given fill and adjust torque using the AutoDockTools 1.5.6 [18].

\subsection{Receptor Preparation}

Receptors are downloaded in the format. pdb then the unused part is removed, added nonpolar hydrogen, given charged, and arranged size and coordinate grid using AutoDockTools 1.5.6 [19]. The receptors used are receptors commonly used to find bacterial cell wall synthesis inhibitors. The part of the receptor used is the site which binds to the comparative ligand, where the active site can be used for natural ligands from these receptors or with previously known inhibitors [20]. For the selected receptor, 2ZDQ, the comparative ligand used is ATP, a natural ligand for the receptor.

\subsection{Molecular Docking}

Molecular docking is done using AutoDock Vina 1.1.2. The parameters used in docking process are the free energy of binding $(\Delta \mathrm{G})$ as a marker of affinity and amino acid's residues as markers of similarity [21]. The more negative $\Delta \mathrm{G}$ shows higher ligand affinity for the active site of the receptor [22]. The highest affinity test ligands were compared with the redocking result from the co-crystal ligand of the receptor by comparing the value of $\Delta \mathrm{G}$ to see if the test ligand has a higher affinity than co-crystal ligands [23]. Amino acid's residues from the highest affinity test ligands were then compared with the results of redocking co-crystal ligands toward receptor to assess the similarity of interactions between the test and co-crystal ligands. The level of similarity is expressed as a percentage that describes the comparison of amino acid residues which are equally present in the test ligands and compared to the total number of amino acid residues in the comparative ligands [8]. The more similar amino acid's residues indicate a higher probability that the test ligand will have similar activity with the cocrystal ligand [24].

\section{Results and Discussion}

Docking results were performed on the entire surface of the receptor with energy range, exhaustiveness, and number of modes parameters score 3, 8 , and 9 , respectively. This number is default parameter for Autodock Vina 1.1.2 for molecular docking purpose [8]. Higher parameter to some degree will increase the accuracy of docking results, although it is not yet measurable how much influence it has [25]. Observation of all receptor surfaces or also known as blind docking is especially necessary because the ligand that will be tested has no known affinity for the particular active site of the receptor. The pose chosen as the representative has the most negative $\Delta \mathrm{G}$ value, indicating the highest probability of the position of the ligand to the receptor [23]. The docking results data of all test ligands and ATP as a comparative ligand to the receptor were compared each other as shown in Table 1. 
Table 1. Docking results from metabolites of bawang dayak toward antimicrobial receptors

\begin{tabular}{|c|c|c|}
\hline Ligand's Number & Ligand's two-dimension structures & $\Delta \mathrm{G}(\mathrm{kcal} / \mathrm{mol})$ \\
\hline $\begin{array}{l}\text { Co-crystal ligand } \\
\text { (ATP) }\end{array}$ & & -8.8 \\
\hline 1 & & -9.1 \\
\hline 2 & & -6.0 \\
\hline 3 & & -6.3 \\
\hline 4 & & -7.2 \\
\hline 5 & & -8.3 \\
\hline 6 & & -8.4 \\
\hline 7 & & -7.0 \\
\hline 8 & & -6.6 \\
\hline 9 & & -7.6 \\
\hline
\end{tabular}


10

11

12

13

14

15

16

17

18

19

20
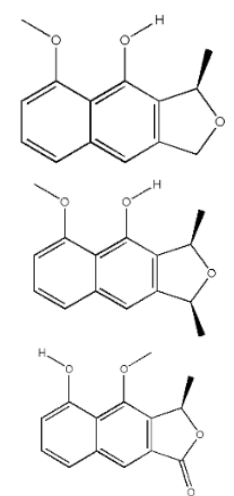

$\underbrace{\mathrm{CHOH}_{3}}_{0}$
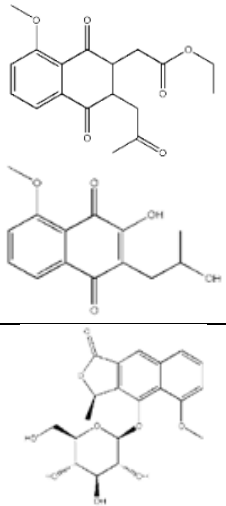

(c)

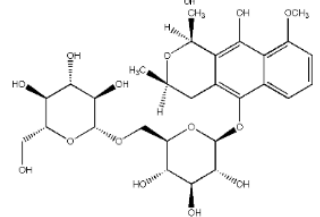

(1)

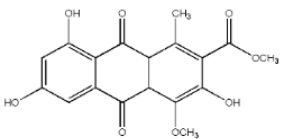

$-9.4$

$-9.0$

$-5.2$

$-5.3$

$-7.2$

$-6.4$

$-6.3$

$-7.0$

$-6.3$

$-7.7$ 


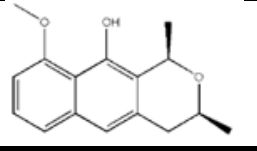

The ligand affinity of the test is indicated by the value of $\Delta \mathrm{G}$, where the more negative the value of $\Delta \mathrm{G}$ indicates the higher ligand affinity [26]. The first interesting point is that all test ligands have a negative $\Delta G$ value, which indicates that the interaction between all test ligands and receptors takes place spontaneously [22]. This is relatively rare, especially in relatively large ligands such as eleuthoside $\mathrm{B}$ and $\mathrm{C}$ because of the possibility of steric barriers at the active site receptor [27]. However, not all test ligands have high affinity, of which from the 24 test ligands there are only three ligands which have higher affinity than natural ligands, in this case ATP. ATP itself is known to have a very high affinity for various types of enzymes such as ligase and kinase which require the presence of phosphate groups, so it is quite difficult to find competitive ligands for ATP [28]. Therefore, the existence of a test affinity with a higher affinity than ATP always attracts attention, especially with a large enough difference of $0.6 \mathrm{kcal} / \mathrm{mol}$ as indicated by eleutherol $\mathrm{A}$.

Eleutherol A, on the one hand actually has a high structural similarity with several other naphthalene group metabolites such as isoeleutherol, eleuthoside, and other eleutherol variants such as eleutherol $\mathrm{B}$ and $\mathrm{C}$ which differ only in one or two functional groups. However, in addition to eleutherol $\mathrm{C}$, almost all of them show relatively low affinity. This phenomenon shows that there are other factors that are the key to the high affinity of eleutherol A in addition to the structure of the compound, in this case most likely is the position of amino acid residues of eleutherol A [29,30]. Observation of amino acid residues shows interesting results as shown in Table 2.

Table 2. Docking results from metabolites of bawang dayak toward antimicrobial receptors

\begin{tabular}{|c|c|c|c|c|}
\hline Ligand & ATP & 1 & 10 & 12 \\
\hline & 116-Lys & - & - & - \\
\hline & 151-Phe & 151-Phe & 151-Phe & 151-Phe \\
\hline & 153-Lys & 153-Lys & 153-Lys & 153-Lys \\
\hline & 160-Ser & - & - & - \\
\hline Amino Acid's & - & - & 163-Ile & 163-Ile \\
\hline \multirow[t]{5}{*}{ Residues } & - & - & - & 189-Glu \\
\hline & - & - & - & 190-Lys \\
\hline & - & - & - & 191-Ala \\
\hline & - & - & - & 192-Leu \\
\hline & - & $195-\mathrm{Val}$ & $195-\mathrm{Val}$ & 195-Val \\
\hline
\end{tabular}




\begin{tabular}{|c|c|c|c|c|}
\hline & 197-Glu & - & - & 197-Glu \\
\hline & 218-Tyr & 218-Tyr & - & 218-Tyr \\
\hline & 222-Phe & - & - & 222-Phe \\
\hline & 223-Tyr & 223-Tyr & 223-Tyr & 223-Тyr \\
\hline & 228-Lys & - & 228-Lys & - \\
\hline & 229-Tyr & - & - & - \\
\hline & - & 272-Phe & 272-Phe & 272-Phe \\
\hline & 281-Asn & - & - & - \\
\hline & 282-Glu & - & - & - \\
\hline & 284-Asn & - & - & - \\
\hline $\begin{array}{c}\text { Percent of similarity } \\
\text { with natural ligand } \\
{[\%]}\end{array}$ & 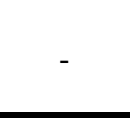 & 30.77 & 30.77 & 46.15 \\
\hline
\end{tabular}

Note: Bold number indicates a similar amino acid's residues between test and co-crystal ligands.

Among the three highest affinity ligands, all have relatively low similarity levels of amino acid residues with comparative ligands. In other words, the type of interaction that occurs between the large test ligands is likely to be different from that which occurs in the comparison ligand [31]. However, it does not mean that if the level of similarity of the amino acid residues is low, then the test ligand cannot provide activities similar to comparative ligands. Visual observation needs to be done to assess the potential difference in amino acid residues to possible differences in activity [32]. The clue is obtained from the results of visual observations as shown in Figure 1.

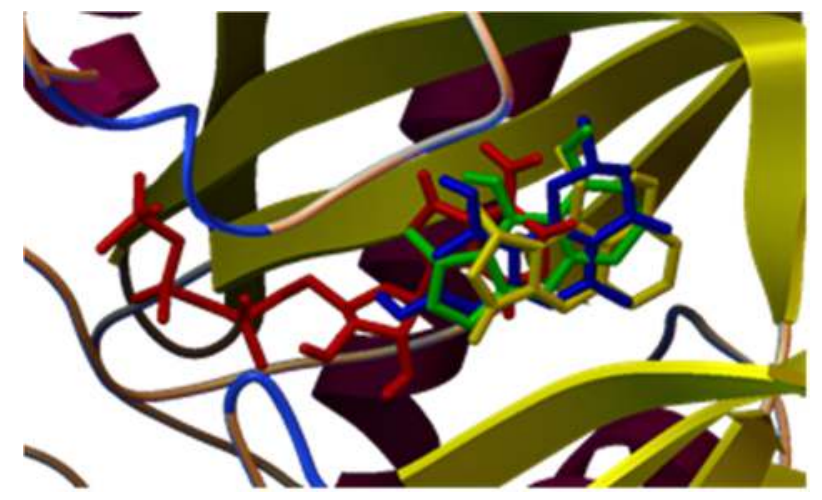

Fig. 1. Comparison of co-crystal ligand (red) of 2ZDQ with test ligand number 1 (blue); 10 (green); and 12 (yellow)

The functional group that must be observed in ATP interactions is the adenosine group, which becomes the "anchor" of the interactions that occur. The part becomes a "fingerprint" group that shows the location of the ATP bond with a protein or enzyme [33]. In other words, if a ligand has a binding pattern similar to that of an adenosine group from ATP, then the ligand is likely to bind to the same active site as ATP [34]. In Figure 1, it can be observed that both ligands number 1, 10, and $\mathbf{1 2}$ have binding locations that are almost identical to the adenosine group. The active site is mainly on amino acid residues between numbers 189 to 229 . Especially for ligand number 12 namely eleutherol $\mathrm{C}$, the interactions in these amino acid regions occur very much. However, the affinity is still lower than ligand number $\mathbf{1 0}$ eleutherol A, indicating 
that although the interaction in the domain is important, does not have a significant effect on the affinity of a ligand [35]. In other words, the affinity of eleutherol A against the 2ZDQ receptor is influenced by other factors besides amino acid residues in the area.

Apart from that, the most important thing is that eleutherol A has a higher affinity than ATP and is highest compared to other test ligands. This means that eleutherol A can compete with ATP to bind to Ddl [36]. The main characteristic of ATP which makes it very reactive in various ligase enzymes is the presence of a high-energy phosphate group which is needed to carry out molecular merging reactions [37]. The absence of a phosphate group on a ligand that binds to the active side of the Ddl as shown by eleutherol A by itself will result in a ligase reaction that cannot occur. Thus, the reaction of cell wall synthesis from bacteria will be inhibited, so that the bacteria will die due to not being able to regenerate their cell walls.

\section{Conclusion}

In conclusion, this study succeeded in obtaining three secondary metabolites from bawang dayak which have potential as cell wall synthesis inhibitors, with the highest affinity shown by eleutherol A. The type of interaction that occurs for these compounds resembles the interaction of the adenosine group of ATPs which is a natural ligand of Ddl as a receptor for cell wall synthesis. The affinity of eleutherol A is even higher than ATP, making it a competitor and potential inhibitor for the synthesis of microbial cell walls. Thus, isolation of eleutherol A from bawang dayak extract can be an alternative to obtain potential antimicrobials from medicinal plants. Furthermore, it is necessary to do in vitro testing to prove the activity of inhibitors of microbial cell wall synthesis from eleutherol A with various types of microbes.

\section{Acknowledgements}

This research was supported by the Universitas Muhammadiyah Palangkaraya through an internal grant scheme from the Research and Community Service Institute Universitas Muhammadiyah Palangkaraya.

\section{References}

[1] Institute of Medicine Forum on Microbial Threats: Microbial evolution and coadaptation: a tribute to the life and scientific legacies of Joshua Lederberg: workshop summary. Washington DC: National Academies Press. doi: 10.17226/12586 (2009)

[2] Wright, P.M., Seiple, I.B., and Myers, A.G.: The Evolving Role of Chemical Synthesis in Antibacterial Drug Discovery. Angew. Chemie Int. Ed., vol. 53, no. 34, pp. 8840 8869. doi: 10.1002/anie.201310843 (2014)

[3] Pan, S.Y., Zhou, S.F., Gao, S.H., Yu, Z.L., Zhang, S.F., Tang, M.K., Sun, J.N., Ma, D.L., Han, Y.F., Fong, W.F., and Ko, K.M.: New Perspectives on How to Discover Drugs from Herbal Medicines: CAM's Outstanding Contribution to Modern Therapeutics. Evidence-Based Complement. Altern. Med., vol. 2013, p. 627375. doi: $10.1155 / 2013 / 627375(2013)$

[4] Chasanah, E.: Marine biodiscovery research in indonesia : challenges and rewards. $J$. Coast. Dev., vol. 12, no. 1, pp. 1-12 (2008)

[5] Nugraha, A.S. and Keller, P.A.: Revealing indigenous Indonesian traditional medicine : anti-infective agents. Nat. Prod. Commun., vol. 6, no. 12, pp. 1953-1966 (2011)

[6] Insanu, M., Kusmardiyani, S., and Hartati, R.: Recent Studies on Phytochemicals and Pharmacological Effects of Eleutherine Americana Merr. Procedia Chem., vol. 13, no. 
2014, pp. 221-228. doi: 10.1016/j.proche.2014.12.032 (2014)

[7] Alves, M.J., Froufe, H.J., Costa, A.F., Santos, A.F., Oliveira, L.G., Osorio, S.R., Abreu, R.M., Pintado, M., and Ferreira, I.C.: Docking studies in target proteins involved in antibacterial action mechanisms: Extending the knowledge on standard antibiotics to antimicrobial mushroom compounds. Molecules, vol. 19, no. 2, pp. 1672-1684. doi: 10.3390/molecules19021672 (2014)

[8] Pratama, M.R.F., Suratno, S., and Mulyani, E.: Antibacterial activity of akar kuning (Arcangelisia flava) secondary metabolites: molecular docking approach. Asian J. Pharm. Clin. Res., vol. 11, no. 11, pp. 447-451. doi: 10.22159/ajpcr.2018.v11i11.29189 (2018)

[9] Davies, J. and Davies, D.: Origins and evolution of antibiotic resistance. Microbiol. Mol. Biol. Rev., vol. 74, no. 3, pp. 417-433. doi: 10.1128/MMBR.00016-10 (2010)

[10] Kitamura, Y., Ebihara, A., Agari, Y., Shinkai, A., Hirotsu, K., and Kuramitsu, S.: Structure of d-alanine-d-alanine ligase from thermus thermophilus HB8: Cumulative conformational change and enzyme-ligand interactions. Acta Crystallogr. Sect. D Biol. Crystallogr., vol. 65, no. 10, pp. 1098-1106. doi: 10.1107/S0907444909029710 (2009)

[11] Batson, S., de Chiara, C., Majce, V., Lloyd, A.J., Gobec, S., Rea, D., Fulop, V., Thoroughgood, C.W., Simmons, K.J., Dowson, C.G., Fishwick, C.W.G., de Carvalho, L.P.S., and Roper, D.I.: Inhibition of D-Ala:D-Ala ligase through a phosphorylated form of the antibiotic D-cycloserine. Nat. Commun., vol. 8, no. 1, pp. 1-7. doi: 10.1038/s41467-017-02118-7 (2017)

[12] Chen, D.L., Hu, M.G., Liu, Y.Y., Li, R.T., Yu, M., Xu, X.D., and Ma, G.X.: New Naphthalene Derivatives from the Bulbs of Eleutherine americana with Their Protective Effect on the Injury of HUVECs. Molecules, vol. 23, no. 9, p. 2111. doi: 10.3390/molecules23092111 (2018)

[13] Alves, T.M.A., Kloos, H., and Zani, C.L.: Eleutherinone, a Novel Fungitoxic Naphthoquinone from Eleutherine bulbosa (Iridaceae). Mem. Inst. Oswaldo Cruz, vol. 98, no. 5, pp. 709-712. doi: 10.1590/S0074-02762003000500021 (2003)

[14] Fernandes, R.A. and Chavan, V.P.: A concise asymmetric synthesis of (-)-hongconin and (-)-1-epi-hongconin. European J. Org. Chem., vol. 61, no. 2, pp. 4306-4311. doi: 10.1002/ejoc.201000560 (2010)

[15] Srinivasu, N., Babu, M.N., and Rao, A.A.: Energy Minimization of CDK2 bound ligands: A Computational Approach. Int. J. Eng. Res. Appl., vol. 2, no. 5, pp. 1884 1887 (2012)

[16] Cui, Q. and Elstner, M.: Density functional tight binding: Values of semi-empirical methods in an ab initio era. Phys. Chem. Chem. Phys., vol. 16, no. 28, pp. 14368-14377. doi: 10.1039/c4cp00908h (2014)

[17] O’Boyle, N.M., Banck, M., James, C.A., Morley, C., Vandermeersch, T., and Hutchison, G.R.: Open Babel: An Open chemical toolbox. J. Cheminform., vol. 3, no. 10, p. 33. doi: 10.1186/1758-2946-3-33 (2011)

[18] Trott, O. and Olson, A.: Autodock vina: improving the speed and accuracy of docking. J. Comput. Chem., vol. 31, no. 2, pp. 455-461. doi: 10.1002/jcc.21334 (2010)

[19] Morris, G.M., Huey, R., Lindstrom, W., Sanner, M.F., Belew, R.K., Goodsell, D.S., and Olson, A.J.: AutoDock4 and AutoDockTools4: Automated docking with selective receptor flexibility. J. Comput. Chem., vol. 30, no. 16, pp. 2785-2791. doi: $10.1002 /$ jcc.21256 (2009)

[20] Munita, J.M. and Arias, C.A.: Mechanisms of Antibiotic Resistance. Microbiol. Spectr., vol. 4, no. 2, pp. 1-37. doi: 10.1128/microbiolspec.VMBF-0016-2015 (2016) 
[21] Pratama, M.R.F. and Gusdinar, T.: Between artemisinin and derivatives with neuraminidase: a docking study insight. Asian J. Pharm. Clin. Res., vol. 10, no. 8, pp. 304-308. doi: 10.22159/ajpcr.2017.v10i8.18667 (2017)

[22] Du, X., Li, Y., Xia, Y.L., Ai, S.M., Liang, J., Sang, P., Ji, X.L., and Liu, S.Q.: Insights into Protein-Ligand Interactions: Mechanisms, Models, and Methods. Int. J. Mol. Sci., vol. 17, no. 2, pp. 1-34. doi: 10.3390/ijms17020144 (2016)

[23] Cui, M., Mihaly, M., Hong-Xing, Z., and Meng, X.Y.: Molecular Docking: A powerful approach for structure-based drug discovery. Curr. Comput. Aided. Drug Des., vol. 7, no. 2, pp. 146-157. doi: 10.2174/157340911795677602 (2011)

[24] Pratama, M.R.F. and Sutomo, S.: Chemical structure optimization of lupeol as ER-A and HER2 inhibitor. Asian J. Pharm. Clin. Res., vol. 11, no. 6, pp. 298-303. doi: 10.22159/ajpcr.2018.v11i6.24226 (2018)

[25] Pagadala, N.S., Syed, K., and Tuszynski, J.: Software for molecular docking: a review. Biophys. Rev., vol. 9, no. 2, pp. 91-102. doi: 10.1007/s12551-016-0247-1 (2017)

[26] Malmstrom, R.D. and Watowich, S.J.: Using free energy of binding calculations to improve the accuracy of virtual screening predictions. J. Chem. Inf. Model., vol. 51, no. 7, pp. 1648-1655. doi: 10.1021/ci200126v (2012)

[27] Monine, M.I., Posner, R.G., Savage, P.B., Faeder, J.R., and Hlavacek, W.S.: Modeling multivalent ligand-receptor interactions with steric constraints on configurations of cellsurface receptor aggregates. Biophys. J., vol. 98, no. 1, pp. 48-56. doi: 10.1016/j.bpj.2009.09.043 (2010)

[28] Krah, A., Kato-Yamada, Y., and Takada, S.: The structural basis of a high affinity ATP binding $\varepsilon$ subunit from a bacterial ATP synthase. PLoS One, vol. 12, no. 5, p. e0177907. doi: 10.1371/journal.pone.0177907 (2017)

[29] Ferreira, L.G., Dos Santos, R.N., Oliva, G., and Andricopulo, A.D.: Molecular docking and structure-based drug design strategies. Molecules, vol. 20, no. 7, pp. 13384-421. doi: 10.3390/molecules200713384 (2015)

[30] Tian, L., Liu, S., Wang, S., and Wang, L.: Ligand-binding specificity and promiscuity of the main lignocellulolytic enzyme families as revealed by active-site architecture analysis. Sci. Rep., vol. 6, no. November 2015, p. 23605. doi: 10.1038/srep23605 (2016)

[31] Barelier, S., Sterling, T., O’Meara, M.J., and Shoichet, B.K.: The Recognition of Unrelated Ligands by Individual Proteins. ACS Chem. Biol., vol. 10, no. 12, pp. 2772 2784. doi: 10.1021/acschembio.8b00443 (2015)

[32] Eisenhaber, F.: Prediction of protein function two basic concepts and one practical recipe. in Madame Curie Bioscience Database. Austin (TX): Landes Bioscience (2013)

[33] Liu, M., Krasteva, M., and Barth, A.: Interactions of phosphate groups of ATP and aspartyl phosphate with the sarcoplasmic reticulum $\mathrm{Ca}^{2}+$-ATPase: An FTIR study. Biophys. J., vol. 89, no. 6, pp. 4352-4363. doi: 10.1529/biophysj.105.061689 (2005)

[34] Sael, L. and Kihara, D.: Detecting Local Ligand-Binding Site Similarity in NonHomologous Proteins by Surface Patch Comparison. Proteins, vol. 80, no. 4, pp. 1177-1195. doi: 10.1002/prot.24018 (2012)

[35] Chen, J., Almo, S.C., and Wu, Y.: General principles of binding between cell surface receptors and multi-specific ligands: A computational study. PLoS Comput. Biol., vol. 13, no. 10, p. e1005805. doi: 10.1371/journal.pcbi.1005805 (2017)

[36] Bruning, J.B., Murillo, A.C., Chacon, O., Barletta, R.G., and Sacchettini, J.C.: Structure of the Mycobacterium tuberculosis D-alanine:D-alanine ligase, a target of the antituberculosis drug D-cycloserine. Antimicrob. Agents Chemother., vol. 55, no. 1, pp. 291-301. doi: 10.1128/AAC.00558-10 (2011) 
[37] Pratama, M.R.F.: Akar Kuning (Arcangelisia Flava) As Neuraminidase Inhibitor: Molecular Docking And Pharmacophore Optimization Approach. in Proceedings of the 2nd Sari Mulia International Conference on Health and Sciences 2017 (SMICHS 2017). Paris: Atlantis Press. doi: 10.2991/smichs-17.2017.63 (2017) 